\title{
Analysis of the Implementation of Good Corporate Governance at PT Nusantara Infrastructure Tbk
}

\author{
Mediaty, Nurleni, Muhammad Muflih Ramlan \\ CV Cipta Gelegar, Ruko Petterani Center Pettarani Makassar, Indonesia \\ dhycka99@gmail.com
}

\begin{abstract}
This paper aims to determine the implementation of the principles of good corporate governance at PT Nusantara Infrastructure Tbk. The principle of good corporate governance included transparency, accountability, responsibility, fairness, and independency. Data collection method in this research is questionnaires and collecting archives and documents. Data were analyzed using descriptive analysis method by using instrument quantitative research test (validity and reliability). The results in this study show that, in general, the principles of good corporate governance have been applied properly in order to protect the interests of companies and shareholders. The analysis of responses shows that the principle of responsibility, fairness, and independency has been applied properly, but still to be improved in several factors. The principle of transparency and accountability has been implemented very well.
\end{abstract}

Keyword: Good corporate governance, principle of good corporate governance, implementation of good corporate governance

\section{Introduction}

Good Corporate Governance (GCG) is one key to success for growing and profitable company in the long term as well as winning the global business competition, especially for companies that have been able to grow and go public. Through a system of good corporate governance of companies can organize, manage and supervise the business control process runs continuously to raise the value of the company. Increased the value of the company can be reached if the company is able to operate with achieving the targeted profit. Through the profits from the company will be able to give dividends to shareholders, enhance the company's growth by maintaining the viability of the company. But in achieving that goal, there are several obstacles to be faced by the company, where such barriers are generally fundamentals. The management is not enough just to make sure that the management process management runs efficiently. Need of new instruments and Good Corporate Governance (GCG) appear to ensure that management is going well, the power of Good Corporate Governance Budianti (2010); the effect of GCG, and business ethic (Pieris \& Nizam, 2008). There are two things that are emphasized in this concept; the importance of the right of shareholders to obtain information correctly and in a timely manner. They are convinced of the profitability of the investment with a reasonable and high value. Second, the company's obligation to make disclosure (disclosure) is accurate, timely, and transparent to all the information the company's performance, ownership, and stakeholder (Thomas, 2006: 1). The businesses in Indonesia also agreed that the implementation of good corporate governance as a system of corporate governance that is good is an important thing, this is evidenced by the signing of Letter of Intent (LOI) with the IMF in 1998, one of the rules is inclusion of schedule improvement of corporate governance in Indonesia (Sulistyanto, 2003). It is then behind the birth of the National Committee on Corporate Governance (KNKCG) in 1999.

Good Corporate Governance is less than the maximum in terms of its implementation among Indonesian companies. One thing that is very contradictory, which on the one hand the application of GCG is believed to be very important in achieving corporate goals is sustainable, but on the other hand, many businesses are reluctant to implement in earnest the reason the impact is less significant to financial performance (survey CLSA, 2004). This contradiction became one of the backgrounds examined the application of the principles of Good Corporate Governance the companies. In this study, which will be conducted by researchers is the implementation of Good Corporate Governance which includes five principles of transparency, accountability, responsibility, fairness, and independency. The object of this study is a company listed on the Indonesia Stock Exchange. But the object of this research is focused on PT. Nusantara Infrastructure Tbk. Reasons for the 
selection of the research object, namely, in addition to satisfactory financial condition, PT. Nusantara Infrastructure Tbk also more accessible so as to minimize the time and cost in the conduct of research.

Research Problem: Based on the background of the problems that have been described, the formulation of the problem in this study is as follows:

- Is the principle of transparency, which is included in the Good Corporate Governance has been applied to PT Nusantara Infrastructure Tbk?

- Is the principle of accountability that is included in the Good Corporate Governance has been applied to PT Nusantara Infrastructure Tbk?

- Does the principle of responsibility are included in the Good Corporate Governance has been applied to PT Nusantara Infrastructure Tbk?

- Does the principle of fairness that is included in the Good Corporate Governance have been applied to PT Nusantara Infrastructure Tbk?

- Does the principle of independence is included in the Good Corporate Governance has been applied to PT Nusantara Infrastructure Tbk?

Research Purposes: Based on the research problem, then the purpose of this study is as follows:

- Understand and see the application of the principle of transparency which is included in the Good Corporate Governance in PT Nusantara Infrastructure.

- Understand and see the application of the principle of accountability that is included in the Good Corporate Governance in PT Nusantara Infrastructure.

- Understand and see the application of the principle of responsibility is included in the Good Corporate Governance in PT Nusantara Infrastructure.

- Understand and see the application of the principles of fairness that is included in the Good Corporate Governance in PT Nusantara Infrastructure.

- Understand and see the application of the principle of independence is included in the Good Corporate Governance in PT Nusantara Infrastructure.

\section{Literature Review}

The Concept of Corporate Governance: Corporate Governance can be defined as a process and structure used by the organs of the company (shareholders or owners of capital, commissioners or board of supervisors and directors) to improve the business and corporate accountability in order to create shareholder value in the long term by taking into account the interests of other stakeholders, based legislation and ethical values (Sutedi, 2011: 1). Good Corporate Governance is one key to success for growing and profitable company in the long term, while winning the global business competition. The economic crisis in Asia and Latin America are believed to arise because of the failure of the implementation of Good Corporate Governance (Setyani, 2010: 2). Good Corporate Governance as well as a pattern of relationships, systems and processes used by the company organs to provide added value that is sustainable in the long term for shareholders to keep into account the interests of other stakeholders, based on legislation and norms. To achieve long-term success, the implementation of good corporate governance principles needs to be guided by integrity. Therefore, a code of conduct that can be a reference for the company's organs and employees in applying the values and business ethics to become part of the corporate culture (Ministry of Finance Study Team Bapepam-LK, 2010: 9). Moeljono (2005: 88) suggests that good corporate governance as a fundamental principle of corporate governance. National Committee on Corporate Governance (KNKCG) in his book Faisal (2003: 3) defines corporate governance as structures, systems and processes used Organ Company sustainable in the long term for shareholders, with regard to other stakeholders, based on legislation and norms.

Single and Amin (2002: 3) that good corporate governance is as a matter relating to effective decision making are sourced from the corporate culture, ethics, values, systems, business processes, policies and organizational structure of the company that aims to encourage and support the development of enterprise, resource management and risk more efficiently and effectively, and corporate responsibility to shareholders and other stakeholders. The concept of good corporate governance is in line with the growing demands of the 
public who want the realization of business life healthy, clean and responsible. This demand is actually a public response to the rampant cases of irregularities corporations around the world. It also reflects the demands of the public wonder why corporate fraud cases could happen anywhere. On the other hand, it is understood that in the era of globalization and the competitive business world increasingly open and competitive companies are required to have good corporate governance which contains provisions how companies referred to behave and act in the face of competition (Antosius, 2003: 1). The main purpose of Good Corporate Governance Usmansyah (2003: 5), namely: 1. Protect the rights and interests of shareholders. 2. Protecting the rights and interests of other stakeholders. 3. Increase the value of the shares and the company. 4. Improve the performance of the Board of Commissioners and Management. 5. Improve the quality of the relationship of the Board of Commissioners and Management. While Supporting Good Corporate Governance means that each company according Herwidayatmo (2003: 7), namely: 1. Formulation of the vision, mission and objectives of the company or organization that is clear. 2. The organizational structure that ensures the balance of the division of tasks and clarity of each task, as well as avoiding overlapping and bureaucratic obstacles. 3. Clarity of responsibilities and authority as well as the mechanism of action. 4. Culture and corporate ethics. 5 . The system of control and performance measurement.

Basic Principles of Good Corporate Governance: Good Corporate Governance is needed to encourage the creation of a market that is efficient, transparent and consistent with the laws. Implementation Good Corporate Governance needs to be supported by three pillars are interconnected, the state, and the device as a regulator, the business world as a market participant, and the community as a user products and business services. The Code of Good Corporate Governance is issued by the Indonesian National Committee for Governance (NCG) in 2006. This research refers to research conducted by Rastiani (2009), entitled Analysis of Implementation of Principles of Good Corporate Governance (GCG) in Relation to Performance PT. Bank Rakyat Indonesia (Persero), Tbk. Where the results of research conducted by using a questionnaire, where each variable gain value amounted to $84.65 \%$ and $84 \%$. This shows that the implementation of the implementation of the principles of Good Corporate Governance (GCG) and the implementation of the performance at PT. Bank Rakyat Indonesia (Persero), Tbk. have been executed better. While the relationship implementation of Good Corporate Governance (GCG) on the performance at PT. Bank Rakyat Indonesia (Persero), Tbk. is the result of the calculation of rank correlation 0.914 or $91.40 \%$, which means having unidirectional relationship is very strong. Furthermore, the coefficient of determinant means that the relationship between the two variables have an influence at $83.53 \%$. Where the implementation of the principles of Good Corporate Governance (GCG) affect the performance of $83.53 \%$ and the remaining $16.47 \%$ influenced by other factors outside the principles of Good Corporate Governance (GCG). The study also draws on research conducted by Febryanto (2013), entitled Analysis of Good Corporate Governance (GCG) Performance Against Company (Empirical Study of Companies Listed in Indonesia Stock Exchange Year 20082012). The study was conducted by collecting the data of 40 manufacturing companies listed in Indonesia Stock Exchange in the form of evidence, records or historical reports that have been compiled in archival or documentary data. Secondary data were obtained from the Indonesia Stock Exchange, Indonesian Capita Market Directory, and Internet. The results of these studies indicate that the effect of GCG in the case of the Independent Board of Commissioners, Board of Directors and Institutional Ownership positive and significant impact on company performance

\section{Methodology}

Research design: The study design is a process of collecting and analyzing research data, and other than that the study design was made for the implementation of the research can be carried out properly, correctly and smoothly. The research design used in this study is related to the quantitative study using inferential statistics through the use of questionnaires.

Location and Time Research: The location of this research is focused on PT. Nusantara Infrastructure Tbk, Bosowa Tower, 4th Floor, Jalan Sudirman No. 5, Makassar, South Sulawesi. This research was conducted in June 2015.

Field Research (Field Research): Collecting data in this study conducted with questionnaires, which is a method or methods of research using a list of questions to be answered by people who are subject to or 
referred to the respondent. According to Hadi (1991: 157), this questionnaire in the shape is based on a report about themselves (self-report) on personal knowledge or belief. Purpose of the questionnaire is to obtain information relevant to the survey objectives and to obtain information that is reliable and valid as high as possible. As instrument this study researchers used a Likert scale, the measurement method used to measure attitudes, opinions and perceptions person or a group of social phenomenon (Sugiyono, 2012: 93).

Population: According Sugiyono (2011: 61) that the population is generalization region consisting object / subjects that have certain qualities and characteristics defined by the researchers to learn and then drawn conclusions.

Data analysis method: The method of analysis used in this study are as follows: Descriptive analysis is an analysis conducted to describe or illustrate the application of the principles of good corporate governance conducted at PT. Nusantara Infrastructure Tbk through questionnaires distributed to a sample of respondents in this study. This study uses a Likert scale to the calculation method of questionnaires distributed to respondents to assess the scale of attitudes of a particular object. The steps used in the application of this method are: a. Determination Score Answers, Scores of the answer is the value of the existing answers given by respondents, according Sugiyono (2012: 94), that the first thing to do is determine the score of each scale answer will be given. This study used a 5 point likert scale: Very Not Good (VNG), No Good (NG), Good Enough (GE), Good (G), Very Good (VG). The following is a table showing each evaluation on the scale used. b. Ideal score, the ideal score is a score used to calculate the scores to determine the rating scale and the total answer. To calculate the total score of the ideal (criterion) of the entire item, use the following formula:

\section{The criterion score $=$ Value Scale $\mathrm{x}$ Number of Respondents}

c. rating Scale

The rating scale is used to overcome the results of the questionnaire data and interviews in general and the overall obtained from the assessment questionnaire.

d. percentage Answer

To determine the number of answers from the respondents by a percentage, which is used the following formula:

Description:

p: percentage

the frequency of each answer

$\mathrm{n}$ : number of ideal score

100: number remains

1. Test Instruments Research

$$
p=\frac{f}{n} x 100 \%
$$

a. Validity test: Test validity is a measure that indicates the validity or validity of an instrument, an instrument is said to be valid if it is able to measure what you want measured (Sugiyono, 2007: 137). Terms of not valid research instrument means that it has a correlation value above 0.25 at a significance level of $5 \%$, and 0.3 at $1 \%$ significance level.

b. test Reliability: Reliability test is an analysis to determine how far the measurement results remain consistent if performed more than twice against the same symptoms with the same measurement tool. Research Instrument is considered reliable if the value of Cronbach's alpha on top of 0.60 . Measurement validity and reliability is absolutely necessary, because if the instruments are no longer valid and reliable research results it certainly would not be valid and reliable.

\section{Results and Discussion}

Validity test: Validity test is used to measure whether or not a legitimate or valid questionnaires. A questionnaire considered valid if the questions on the questionnaire were able to reveal something that will be measured by the questionnaire. This study uses SPSS software to analyze the questionnaire data obtained so as to produce output that is called Pearson Correlation by comparing the count and the r-r-correlation 
tables are the result of respondents' answers to each question (indicator of any GCG). Test analysis in this study is said to be valid if it has a value of Pearson Correlation above 0.25 at a significance level of $5 \%$ and 0.3 at a significance level of $1 \%$. The following is a table of test results the validity of the principles of transparency, accountability, responsibility, fairness, and independence:

Reliability test: Reliability test is used to determine whether the indicators used are trustworthy or reliable as a measurement variable and can be used twice on the same symptoms and the same measuring instrument. Reliability of a questionnaire can be seen from the value of Cronbach's Alpha ( $\alpha$ ), i.e. when the value is greater than 0.6. Meanwhile, when the value of Cronbach's Alpha $(\alpha)$ is smaller than 0.6, the indicators used are not reliable. The following table shows the results of reliability test on any good corporate governance principles are used. Cronbach's Alpha value of the indicator shows the number above 0.60, so it can be said that the indicators used in the questionnaire on the principles of Good Corporate Governance otherwise reliable or trustworthy.

\section{Table 1: Validity of Test Results}

\begin{tabular}{|c|c|c|c|c|}
\hline Principle & $\begin{array}{l}\text { Code } \\
\text { Indicator }\end{array}$ & $\begin{array}{l}\text { Pearson } \\
\text { Correlation }\end{array}$ & R table & Description \\
\hline \multirow[t]{3}{*}{ Transparency } & $\mathrm{x} 1.1$ & 0.590 & 0.30 & Valid \\
\hline & $\begin{array}{l}\mathrm{x} 1.2 \\
\mathrm{x} 1.3\end{array}$ & $\begin{array}{l}0.606 \\
0.581\end{array}$ & $\begin{array}{l}0.30 \\
0.30\end{array}$ & $\begin{array}{l}\text { Valid } \\
\text { Valid }\end{array}$ \\
\hline & $\mathrm{x} 1.4$ & 0.290 & 0.25 & Valid \\
\hline \multirow[t]{4}{*}{ Accountability } & $\mathrm{x} 2.1$ & 0.316 & 0.30 & Valid \\
\hline & $\mathrm{x} 2.2$ & 0.859 & 0.30 & Valid \\
\hline & $\mathrm{x} 2.3$ & 0.836 & 0.30 & Valid \\
\hline & $\mathrm{x} 2.4$ & 0.749 & 0.30 & Valid \\
\hline \multirow[t]{4}{*}{ Responsibility } & $\mathrm{x} 3.1$ & 0.395 & 0.30 & Valid \\
\hline & $\mathrm{x} 3.2$ & 0.512 & 0.30 & Valid \\
\hline & x3.3 & 0.434 & 0.30 & Valid \\
\hline & x3.4 & 0.352 & 0.30 & Valid \\
\hline \multirow[t]{4}{*}{ Fairness } & $\mathrm{x} 4.1$ & 0.568 & 0.30 & Valid \\
\hline & $\mathrm{x} 4.2$ & 0.487 & 0.30 & Valid \\
\hline & $x 4.3$ & 0.578 & 0.30 & Valid \\
\hline & $\mathrm{x} 4.4$ & 0.670 & 0.30 & Valid \\
\hline \multirow[t]{4}{*}{ Independence } & $\mathrm{x} 5.1$ & 0.587 & 0.30 & Valid \\
\hline & $\mathrm{x} 5.2$ & 0.609 & 0.30 & Valid \\
\hline & $\mathrm{x} 5.3$ & 0.680 & 0.30 & Valid \\
\hline & x5.4 & 0.626 & 0.30 & Valid \\
\hline
\end{tabular}

Source: Appendix SPSS

The above table shows the Pearson Correlation numbers above 0.25 and 0.3 are all indicators show that the question of the application of the principles of good corporate governance has been valid. For more details about the validity of the results of the test using SPSS program will be presented in the appendix. 
Table 2: Reliability Test Results

\begin{tabular}{llll}
\hline Indicator & $\begin{array}{l}\text { Cronbach's } \\
\text { Alpha }(\boldsymbol{\alpha})\end{array}$ & $\begin{array}{l}\text { Reliabilities } \\
\text { Standard }\end{array}$ & Description \\
\hline $\begin{array}{l}\text { Transparency } \\
(\mathrm{x} .1 .1, \mathrm{x} 1.2, \mathrm{x} 1.3, \mathrm{x} 1.4)\end{array}$ & 0.660 & 0.60 & Reliable \\
$\begin{array}{l}\text { Accountability } \\
\text { (x2.1, x2.2, x2.3, x2.4) }\end{array}$ & 0.779 & 0.60 & Reliable \\
$\begin{array}{l}\text { Responsibility } \\
(\mathrm{x} 3.1, \mathrm{x} 3.2, \mathrm{x} 3.3,3.4)\end{array}$ & 0.711 & 0.60 & Reliable \\
$\begin{array}{l}\text { Fairness } \\
(\mathrm{x} 4.1, \mathrm{x} 4.2, \mathrm{x} 4.3, \mathrm{x} 4.4)\end{array}$ & 0.690 & 0.60 & Reliable \\
$\begin{array}{l}\text { Independence } \\
(\mathrm{x} 5.1, \mathrm{x} 5.2, \mathrm{x} 5.3, \mathrm{x} 5.4)\end{array}$ & 0.736 & 0.60 & Reliable \\
\hline
\end{tabular}

Source: Appendix SPSS

Descriptive Analysis Research on Implementation of Principles of Good Corporate Governance: Each company must ensure that the principles of good corporate governance applied to the business aspects and at all levels of the company. It aims to encourage the creation of a market that is efficient, transparent, and consistent with the laws .Good Corporate Governance is good corporate governance, which in this study emphasized on PT Nusantara Infrastructure Tbk. It is very important to consider the company in determining the objectives to be achieved in the operational management of the company. The following are the responses of respondents regarding the implementation of corporate governance principles in the company so that it can be seen how much the implementation of GCG in PT Nusantara Infrastructure Tbk. This study uses a Likert scale of measurement in the data analysis. Here is a description of the measures used for analysis with Likert scale measurement methods:

Scoring answers: This study uses five point likert scales and each scale response was assessed with each score. Answer Very Not Good (VNG) rated with a score of 1, answer Not Good (NG) rated with a score of 2, answers Good Enough (GE) were assessed with a score of 3, the answer Good (G) rated with a score of 4, the answer Very Good (VG) rated with a score of 5 (table 3.1.1 Scale Answer).

Score Ideal: Ideal score is determined using the following formula:

The criterion score $=$ Value Scale $\mathbf{x}$ Number of Respondents: In this study, determined the number of respondents as many as 61 people. Each of Good Corporate Governance has four indicators, so each time you answer a questionnaire at each scale accumulated answers first. Multiplied by the total number of respondents so that the indicator is 244 respondents. So the ideal score obtained is presented in the following table:

Table 3: Ideal score for each scale

\begin{tabular}{ll}
\hline Score Ideal & Scale \\
\hline $5 \times 244=1.220$ & VG \\
$4 \times 244=976$ & G \\
$3 \times 244=732$ & GE \\
$2 \times 244=488$ & NG \\
$1 \times 244=244$ & VNG \\
\hline
\end{tabular}

The table shows that the ideal score for each scale the answer is: 1.220 to scale Very Good (VG), 976 on a scale of Good (G), 732untuk scale Good Enough (GE), 488 to scale Not Good (NG), and 244 to scale very Not Good (VNG). 
Rating Scale: Value rating scale and distance interval taken by ideal score table, so it can be described as follows:

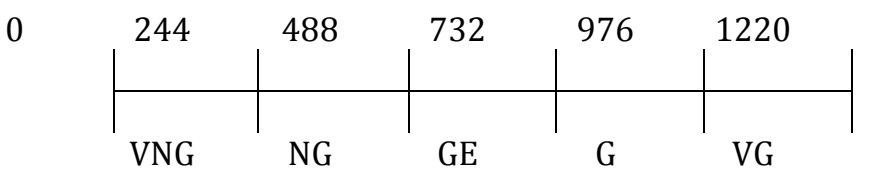

With the following conditions:

Based on the table, can be classified, within the interval 0-244 in the category Very Not Good (VNG), the distance interval 245-488 in the category No Good (NG), the distance interval 489-732 in the category Good Enough (GE), distance interval 733-976 in the category Good (G), and the distance interval 977-1220 in the category of Very Good (VG).

Table 4: Value answer to Scale Answer

\begin{tabular}{ll}
\hline Value & Scale \\
\hline $977-1.220$ & VG \\
$733-976$ & G \\
$489-732$ & GE \\
$245-488$ & NG \\
$0-244$ & VNG \\
\hline
\end{tabular}

Percentage Answer: Calculating the percentage using the formula:

Description:

p: percentage

the frequency of each answer

$\mathrm{n}$ : number of ideal score $=1.220$

100: number remains

$$
p=\frac{f}{n} x 100 \%
$$

Respondents Regarding Transparency: Transparency, the basic principle is to maintain objectivity in doing business, companies must provide information that is material and relevant in a way that is easily accessible and understood by stakeholders. Enterprises should take the initiative to express not only the problem that required by legislation, but also things that are important for decision-making by shareholders, creditors and other stakeholders. For more details, the following will be presented respondents regarding the principle of transparency, which can be viewed through the following table:

Table 5: Respondents about Transparency

\begin{tabular}{|c|c|c|c|c|c|c|c|}
\hline \multirow{2}{*}{ No } & \multirow{2}{*}{ Statement } & \multicolumn{3}{|c|}{ Respondents } & \multirow[b]{2}{*}{ G } & \multirow[b]{2}{*}{ VG } & \multirow{2}{*}{ Total } \\
\hline & & VNG & NG & GE & & & \\
\hline 1 & $\begin{array}{l}\text { Development and application of } \\
\text { accounting system based on } \\
\text { accounting standards and ensure } \\
\text { financial reporting and disclosure. }\end{array}$ & - & - & $\begin{array}{l}6 \\
9.8 \%\end{array}$ & $\begin{array}{l}17 \\
27.8 \%\end{array}$ & $\begin{array}{l}38 \\
62.3 \%\end{array}$ & 61 \\
\hline 2 & $\begin{array}{l}\text { The development and application of } \\
\text { information technology management. }\end{array}$ & - & - & $\begin{array}{l}9 \\
14.8 \%\end{array}$ & $\begin{array}{l}34 \\
55.7 \%\end{array}$ & $\begin{array}{l}18 \\
29.5 \%\end{array}$ & 61 \\
\hline 3 & $\begin{array}{l}\text { Application of risk management within } \\
\text { the enterprise level. }\end{array}$ & - & - & $\begin{array}{l}13 \\
21.3 \%\end{array}$ & $\begin{array}{l}41 \\
67.2 \%\end{array}$ & $\begin{array}{l}7 \\
11.5 \%\end{array}$ & 61 \\
\hline 4 & $\begin{array}{l}\text { Condensed financial information and } \\
\text { other information material. }\end{array}$ & - & - & $\begin{array}{l}4 \\
6.6 \%\end{array}$ & $\begin{array}{l}51 \\
83.6 \%\end{array}$ & $\begin{array}{l}6 \\
9.8 \%\end{array}$ & 61 \\
\hline Total & & - & - & $\begin{array}{l}31 \\
13.1 \%\end{array}$ & $\begin{array}{l}143 \\
58.6 \%\end{array}$ & $\begin{array}{l}69 \\
28.3 \%\end{array}$ & 244 \\
\hline
\end{tabular}

Source: Primary Data 2015 
Table 6: Results Total Scale Score Answer Transparency

\begin{tabular}{lll}
\hline Scale answers & Scale answer $x$ scale value & Result \\
\hline VNG & - & - \\
NG & - & - \\
GE & $31 \times 3$ & 93 \\
G & $143 \times 4$ & 572 \\
VG & $69 \times 5$ & 345 \\
Total & & 1.010 \\
\hline
\end{tabular}

Source: Primary Data 2015

Based on the results of the questionnaire, it can be said that the average respondent to respond to selection Good (G) of the principle of transparency that is equal to $58.6 \%$. The above table shows that three out of four statements is dominated by a large selection of Good (G). $62.3 \%$ of respondents opting to Very Good (VG) in a statement that the company has developed an accounting system based on accounting standards and ensure financial reporting and disclosure. In a second statement that companies develop information technology management, shows that $55.7 \%$ of respondents choose the option Good (G). The third statement that the company developed a risk management within the enterprise level is dominated by a large selection of Good (G) of $67.2 \%$. In the fourth option that the company publishes financial information and other information material, most respondents chose a selection Good (G). The above data is then used as the basis used to measure the Likert scale on the responses of respondents regarding the principle of transparency. Based on these data, the results of the scoring are presented in the following table. The above results indicate that the total score of the principle of transparency is 1.010. Based on the rating scale that has been determined, then a score of 1,010 into the local scale of Very Good (VG). Percentage of responses from the total score of the above percentages are calculated using the formula $=$ frequency of each answer the questionnaire: the number of ideal score $\mathrm{x} 100 \%$, the percentage is $1.010: 1.220 \times 100 \%=82.8 \%$.

Respondents on Accountability: Accountability, the company's basic principles include accountability for its performance transparent and fair manner. Companies must be properly managed, scalable, and in accordance with the interests of the company by taking into account the interests of shareholders and other stakeholders. Performance of sustainable enterprises can be achieved by applying the principle of accountability. The table below shows the responses of respondents regarding the principle of accountability within the company.

Table 7: Respondents on Accountability

\begin{tabular}{|c|c|c|c|c|c|c|c|}
\hline \multirow{2}{*}{ No } & \multirow{2}{*}{ Statement } & \multicolumn{5}{|c|}{ Respondent } & \multirow{2}{*}{ Total } \\
\hline & & VNG & NG & GE & G & VG & \\
\hline 1 & $\begin{array}{l}\text { Implementation of the audit } \\
\text { committee. }\end{array}$ & - & - & $\begin{array}{l}3 \\
4.9 \%\end{array}$ & $\begin{array}{l}42 \\
68.9 \%\end{array}$ & $\begin{array}{l}16 \\
26.2 \%\end{array}$ & 61 \\
\hline 2 & $\begin{array}{l}\text { Implementation of the role and } \\
\text { function of internal auditor. }\end{array}$ & - & - & $\begin{array}{l}6 \\
9.8 \%\end{array}$ & $\begin{array}{l}7 \\
11.5 \%\end{array}$ & $\begin{array}{l}48 \\
78.9 \%\end{array}$ & 61 \\
\hline 3 & Implementation of job grading system. & - & - & $\begin{array}{l}5 \\
8.2 \%\end{array}$ & $\begin{array}{l}9 \\
14.8 \%\end{array}$ & $\begin{array}{l}47 \\
77 \%\end{array}$ & 61 \\
\hline 4 & $\begin{array}{l}\text { The use of external auditors is } \\
\text { qualified and independent. }\end{array}$ & - & $\begin{array}{l}3 \\
4.9 \%\end{array}$ & $\begin{array}{l}18 \\
29.5 \%\end{array}$ & $\begin{array}{l}29 \\
47.5 \%\end{array}$ & $\begin{array}{l}11 \\
18.1 \%\end{array}$ & 61 \\
\hline Total & & - & $\begin{array}{l}3 \\
1.2 \% \\
\end{array}$ & $\begin{array}{l}32 \\
13.1 \%\end{array}$ & $\begin{array}{l}87 \\
35.7 \% \\
\end{array}$ & $\begin{array}{l}122 \\
50 \%\end{array}$ & 244 \\
\hline
\end{tabular}

Source: Primary Data 2015

Based on the above table, as much as $50 \%$ of respondents provide options Very Good (SB). In the first statement, the company set up an audit committee, $68.9 \%$ of respondents chose Good (B). While in the second statement, the majority of which is as much as $78.9 \%$ of respondents chose a selection Very Good (VG). The third statement that the company establishes a performance evaluation system is dominated by the respondents chose Very Good (VG) that is equal to 77\%. Most respondents choose the option Good (G) in the 
fourth statement; the company uses qualified external auditors and independent. The data used as the basis used for the measurement with the Likert scale on the responses of respondents regarding the principle of accountability. Based on these data, the results of the scoring are presented in the following table:

\section{Table 8: Results Total Scale Score Answer Accountability Principles}

\begin{tabular}{lll}
\hline Scale answers & Scale answer $\mathbf{x}$ scale value & Result \\
\hline VNG & - & - \\
NG & $3 \times 2$ & 6 \\
GE & $32 \times 3$ & 96 \\
G & $87 \times 4$ & 348 \\
VG & $122 \times 5$ & 610 \\
Total & & 1.060 \\
\hline
\end{tabular}

Source: Primary Data 2015

The above results indicate that the total score of the principle of accountability is 1.060. Based on the rating scale that has been determined, then a score of 1060 into the local scale of Very Good (VG)). Percentage of responses from the total score of the above percentages are calculated using the formula $=$ frequency of each answer the questionnaire: the number of ideal score $\mathrm{x} 100 \%$, the percentage is $1.060: 1.220 \times 100 \%=86.9 \%$.

Respondents Regarding Responsibility: Companies must meet legislation and to implement responsibilities towards society and the environment so that it can maintain the continuity of the business in the long term and to be recognized as a good corporate citizen. Here are the responses of respondents regarding the principle of responsibility within the company.

\section{Table 9: Respondents Regarding Responsibility}

\begin{tabular}{|c|c|c|c|c|c|c|c|}
\hline \multirow{2}{*}{ No } & \multirow{2}{*}{ Statement } & \multicolumn{5}{|c|}{ Respondent } & \multirow{2}{*}{ Tota } \\
\hline & & VNG & NG & GE & G & VG & \\
\hline 1 & $\begin{array}{lll}\text { Companies } & \text { consider } & \text { social } \\
\text { responsibility. } & & \end{array}$ & - & $\begin{array}{l}2 \\
3.3 \%\end{array}$ & $\begin{array}{l}22 \\
36.1 \%\end{array}$ & $\begin{array}{l}28 \\
45.9 \%\end{array}$ & $\begin{array}{l}9 \\
14.8 \%\end{array}$ & 61 \\
\hline 2 & Companies avoid the abuse of power. & - & $\begin{array}{l}1 \\
1.6 \%\end{array}$ & $\begin{array}{l}15 \\
24.6 \%\end{array}$ & $\begin{array}{l}38 \\
62.3 \%\end{array}$ & $\begin{array}{l}7 \\
11.5 \%\end{array}$ & 61 \\
\hline 3 & $\begin{array}{l}\text { Private company formed a } \\
\text { professional and adheres to ethics. }\end{array}$ & $\begin{array}{l}1 \\
1.6 \%\end{array}$ & $\begin{array}{l}13 \\
21.3 \%\end{array}$ & $\begin{array}{l}25 \\
41 \%\end{array}$ & $\begin{array}{l}20 \\
32.8 \%\end{array}$ & $\begin{array}{l}2 \\
3.3 \%\end{array}$ & 61 \\
\hline 4 & $\begin{array}{l}\text { The company creates good business } \\
\text { environment. }\end{array}$ & $\begin{array}{l}1 \\
1.6 \%\end{array}$ & $\begin{array}{l}2 \\
3.3 \%\end{array}$ & $\begin{array}{l}16 \\
26.2 \%\end{array}$ & $\begin{array}{l}38 \\
62.3 \%\end{array}$ & $\begin{array}{l}4 \\
6.6 \%\end{array}$ & 61 \\
\hline Total & & $\begin{array}{l}2 \\
0.8 \%\end{array}$ & $\begin{array}{l}18 \\
7.4 \%\end{array}$ & $\begin{array}{l}78 \\
32 \%\end{array}$ & $\begin{array}{l}124 \\
50.8 \%\end{array}$ & $\begin{array}{l}22 \\
9.0 \%\end{array}$ & 244 \\
\hline
\end{tabular}

Source: Primary Data 2015

The above table shows that the majority of respondents (50.8\%) chose a selection Good (G) concerning liability company. The first statement that companies consider social responsibility is dominated by the respondents who choose the option Good (G) that is equal to 45.9\%. The second option, companies avoid the abuse of power, shows that the majority of respondents chose a selection Good (G) that is equal to $62.3 \%$. Respondents were also dominant choose Enough Good selection (GE) in the third statement that the company established a personal professional and adhere to ethics (41\%). By $62.3 \%$ of respondents choose the option Good $(\mathrm{G})$ on the fourth option, the company created a good business environment. The above data is then used as the basis used to measure the Likert scale on the responses of respondents regarding the principle of responsibility. Based on these data, the results of the scoring are presented in the following table: 
Table 10: Results Total Scale Score Answer Principle Responsibility

\begin{tabular}{lll}
\hline Scale answers & Scale answer $x$ scale value & Result \\
\hline VNG & $2 \times 1$ & 2 \\
NG & $18 \times 2$ & 36 \\
GE & $78 \times 3$ & 234 \\
G & $124 \times 4$ & 496 \\
VG & $22 \times 5$ & 110 \\
Total & & 878 \\
\hline
\end{tabular}

Source: Primary Data 2015

The above results show that a total score of 878 . Based on the principle that responsibility rating scale that has been determined, then a score of 878 into the local scale of Good (G). Percentage of responses from the total score of the above percentages are calculated using the formula = frequency of each answer the questionnaire: the number of ideal score $\mathrm{x} 100 \%$, the percentage is $878: 1220 \mathrm{x} 100 \%=72 \%$.

Respondents Regarding Fairness: Companies in the implementation of its activities should always take into consideration the interests of shareholders and other stakeholders based on the principles of equality and fairness. Companies should give provide fair and equitable treatment to stakeholders in accordance with the benefits and contributions made to the company. The following table describes the responses of respondents regarding the principles of fairness in its implementation in the company.

Table 11: Respondents Regarding Fairness

\begin{tabular}{|c|c|c|c|c|c|c|c|}
\hline \multirow{2}{*}{ No } & \multirow{2}{*}{ Statement } & \multicolumn{5}{|c|}{ Respondent } & \multirow{2}{*}{ Total } \\
\hline & & VNG & NG & GE & G & VG & \\
\hline 1 & $\begin{array}{l}\text { Application of the company's rules } \\
\text { on the protection of the interests of } \\
\text { shareholders. }\end{array}$ & - & $\begin{array}{l}2 \\
3.3 \%\end{array}$ & $\begin{array}{l}15 \\
24.6 \%\end{array}$ & $\begin{array}{l}41 \\
67.2 \%\end{array}$ & $\begin{array}{l}3 \\
5 \%\end{array}$ & 61 \\
\hline 2 & $\begin{array}{l}\text { Implementation of policies to } \\
\text { protect against errors that comes } \\
\text { from within. }\end{array}$ & $\begin{array}{l}1 \\
1.6 \%\end{array}$ & $\begin{array}{l}18 \\
29.5 \%\end{array}$ & $\begin{array}{l}23 \\
37.7 \%\end{array}$ & $\begin{array}{l}17 \\
27.9 \%\end{array}$ & $\begin{array}{l}2 \\
3.3 \%\end{array}$ & 61 \\
\hline 3 & $\begin{array}{l}\text { Implementation of the roles and } \\
\text { responsibilities of commissioners } \\
\text { and management. }\end{array}$ & - & - & $\begin{array}{l}9 \\
14.8 \%\end{array}$ & $\begin{array}{l}36 \\
59 \%\end{array}$ & $\begin{array}{l}16 \\
26.2 \%\end{array}$ & 61 \\
\hline 4 & Disclosure of any information fair. & - & - & $\begin{array}{l}14 \\
23 \%\end{array}$ & $\begin{array}{l}34 \\
55.7 \%\end{array}$ & $\begin{array}{l}13 \\
21,3 \%\end{array}$ & 61 \\
\hline Total & & $\begin{array}{l}1 \\
0.4 \%\end{array}$ & $\begin{array}{l}20 \\
8.2 \%\end{array}$ & $\begin{array}{l}61 \\
25 \%\end{array}$ & $\begin{array}{l}128 \\
52.2 \%\end{array}$ & $\begin{array}{l}34 \\
14 \%\end{array}$ & 244 \\
\hline
\end{tabular}

Source: Primary Data 2015

According to the table above concerning the principles of fairness, the average respondent provides an option Good (G) that is equal to $52.2 \%$. The first statement that the company establishes firm rules to protect the interests of shareholders, $67.2 \%$ of respondents opting Good $(\mathrm{G})$. In a second statement that the company established a policy to protect against errors that comes from within, most respondents $(37.7 \%)$ chose a selection of Good Enough (GE). As many as 59\% of respondents choose the option Good (B) on the company's statement establishes the roles and responsibilities of commissioners and management. In a recent statement that the company discloses any information fairly, amounting to $55.7 \%$ of respondents choose the option Good (G). The above data is then used as the basis used to measure the Likert scale on the responses of respondents regarding the principles of fairness. Based on these data, the results of the scoring are presented in the following table: 
Table 12: Results Total Scale Score Answer Principle of Fairness

\begin{tabular}{lll}
\hline Scale answers & Scale answer x scale value & Result \\
\hline VNG & $1 \times 1$ & 1 \\
NG & $20 \times 2$ & 40 \\
GE & $61 \times 3$ & 183 \\
G & $128 \times 4$ & 512 \\
VG & $34 \times 5$ & 170 \\
Total & & 906 \\
\hline
\end{tabular}

Source: Primary Data 2015

The above results show that a total score of 906. Based on the principle of fairness that rating scale that has been determined, then a score of 906 into the local scale of Good (G). Percentage of responses from the total score of the above percentages are calculated using the formula $=$ frequency of each answer the questionnaire: the number of ideal score $\mathrm{x} 100 \%$, the percentage is $906: 1220 \times 100 \%=74.3 \%$.

Respondents Regarding Independence: The basic principle is to launch deploy the principles of Good Corporate Governance; the company must be managed independently so that each organ of the company does not dominate the other and cannot be interfered with by other parties. This can be demonstrated by not involving the influence of outside parties that are not in accordance with the principles of corporate and avoid conflicts of interest so that the activity of the company is doing well and dynamic. Here is a table that describes the application of the principle of the independence of the company:

Table 13: Respondents Regarding Independence

\begin{tabular}{|c|c|c|c|c|c|c|c|}
\hline \multirow{2}{*}{ No } & \multirow{2}{*}{ Statement } & \multicolumn{2}{|c|}{ Respondent } & \multirow[b]{2}{*}{ GE } & \multirow[b]{2}{*}{ G } & \multirow[b]{2}{*}{ VG } & \multirow{2}{*}{ Total } \\
\hline & & VNG & NG & & & & \\
\hline 1 & $\begin{array}{l}\text { The use of experts in financial } \\
\text { reporting. }\end{array}$ & $\begin{array}{l}1 \\
1.6 \%\end{array}$ & $\begin{array}{ll}2 \\
3.3 \%\end{array}$ & $\begin{array}{l}24 \\
39.4 \%\end{array}$ & $\begin{array}{l}23 \\
37.7 \%\end{array}$ & $\begin{array}{l}11 \\
18 \%\end{array}$ & 61 \\
\hline 2 & $\begin{array}{l}\text { Companies avoid the involvement } \\
\text { of the influence of outside parties } \\
\text { that are not in accordance with the } \\
\text { principles of healthy corporate. }\end{array}$ & - & $\begin{array}{l}2 \\
3.3 \%\end{array}$ & $\begin{array}{l}19 \\
31.1 \%\end{array}$ & $\begin{array}{l}32 \\
52.5 \%\end{array}$ & $\begin{array}{l}8 \\
13.1 \%\end{array}$ & 61 \\
\hline 3 & $\begin{array}{l}\text { Companies avoid conflicts of } \\
\text { interest. }\end{array}$ & - & $\begin{array}{l}1 \\
1.6 \%\end{array}$ & $\begin{array}{l}7 \\
11.5 \%\end{array}$ & $\begin{array}{l}41 \\
67.2 \%\end{array}$ & $\begin{array}{l}12 \\
19.7 \%\end{array}$ & 61 \\
\hline 4 & $\begin{array}{l}\text { Companies run the activities of the } \\
\text { company with a good and dynamic. }\end{array}$ & - & - & $\begin{array}{l}14 \\
23 \%\end{array}$ & $\begin{array}{l}31 \\
51 \%\end{array}$ & $\begin{array}{l}16 \\
26.2 \%\end{array}$ & 61 \\
\hline Total & & $\begin{array}{l}2 \\
0.82 \%\end{array}$ & $\begin{array}{l}11 \\
4.5 \%\end{array}$ & $\begin{array}{l}68 \\
27.9 \%\end{array}$ & $\begin{array}{l}122 \\
50 \%\end{array}$ & $\begin{array}{l}41 \\
16.8 \%\end{array}$ & 244 \\
\hline
\end{tabular}

Source: Primary Data 2015

The above table shows that the principle of independence, the majority of respondents, $50 \%$ chose a selection Good (G). In the first statement on the use of experts in financial reporting, dominant respondents chose Good Enough selection (GE) that is equal to $39.4 \%$. A total of $52.5 \%$ of respondents in a statement that the company does not involve the influence of outside parties that are not in accordance with the principles of healthy corporate, choose the option Good (G). In the third statement of the company to avoid any conflict of interest, $51 \%$ of respondents choose the option Good (G). In a recent statement that the company runs activities of the company with a good and dynamic, as much as $51 \%$ of respondents opting Good (G). The above data is then used as the basis used to measure the Likert scale on the responses of respondents regarding the principle of independence. Based on these data, the results of the scoring are presented in the following table: 
Table 14: Results Total Scale Score Answer Principle independence

\begin{tabular}{lll}
\hline Scale answers & Scale answer x scale value & Result \\
\hline VNG & $2 \times 1$ & 2 \\
NG & $11 \times 2$ & 22 \\
GE & $68 \times 3$ & 204 \\
G & $122 \times 4$ & 488 \\
VG & $41 \times 5$ & 205 \\
Total & & 921 \\
\hline
\end{tabular}

Source: Primary Data 2015

Table 15: Recapitulation Calculation Results Questionnaire

\begin{tabular}{lll}
\hline GCG Principle & Percentage & Criteria \\
\hline Transparency & $82.8 \%$ & Very good \\
Accountability & $86.9 \%$ & Very good \\
Responsibility & $72 \%$ & Good \\
Fairness & $74.3 \%$ & Good \\
The independence & $75.5 \%$ & Good \\
\hline
\end{tabular}

The above results show that a total score of 921. Based on the principle of the independence of the rating scale that has been determined, then a score of 921 into the local scale of Good (G). Percentage of responses from the total score of the above percentages are calculated using the formula = frequency of each answer the questionnaire: the number of ideal score $\mathrm{x} 100 \%$, the percentage is $921: 1220 \times 100 \%=75.5 \%$.

Recapitulation Calculation Results Questionnaire: Based on data analysis using a Likert scale questionnaire on every principle of Good Corporate Governance (GCG), the recapitulation of the calculation of the questionnaire are presented in the following table.

Based on the analysis of questionnaires regarding the judgment relating to the implementation of good corporate governance as a means of accountability at PT Nusantara Infrastructure Tbk, it can be described as follows: 1. Application of the principle of transparency in PT Nusantara Infrastructure Tbk, which is Very Good with the score total of answer scale is 1,010 with a percentage of $82.8 \%$. It is clear that the majority of respondents stated that the company is open in presenting material and relevant information as well as open in the decision making process. 2. Application of the principle of accountability at PT Nusantara Infrastructure Tbk, which is Very Good with the score total of answer scale, is 1,060 with a percentage of $86.9 \%$. It is clear that clarity of function and implementation of organ liability company ran very effectively. 3. Application of the principle responsibility of PT Nusantara Infrastructure Tbk, namely Good with the score total of answer scale is 878 with a percentage of $72 \%$. It is clear that there is conformity and compliance in the management of the company towards healthy corporate principles appropriate legislation and regulations. 4. The application of the principle of fairness in PT Nusantara Infrastructure Tbk, namely Good with the score total of answer scale is 906 with a percentage of $74.3 \%$. This shows that in the fulfillment of the rights of stakeholders arising under treaties and legislation conducted in a fair and equal. 5. Application of the principle of independence of PT Nusantara Infrastructure Tbk, namely Good with the score total of answer scale is 921 with a percentage of $75.5 \%$. This shows that a professionally managed company with no conflicts of interest and pressures from any party that does not comply with the legislation in force and the principles of healthy corporate.

\section{Conclusion}

Based on the results of research supported by the data and information that has been stated previously, the authors conclude that good corporate governance (GCG) at PT Nusantara Infrastructure Tbk in general has been well implemented. Here are the conclusions drawn from each of the GCG principles that have been 
applied by PT Nusantara Infrastructure Tbk: Application of the principle of transparency. Indicators that have been implemented very well are the first indicator of the development of the accounting system based on accounting standards and ensure financial reporting and disclosure. While other indicators are still in the good category. The results of the total score of the scale of the answer are 1,010 with a percentage of $82.8 \%$. So it can be concluded that in general the principle of transparency has been implemented very well. Application of the principle of accountability. Indicators that have been applied with a very good second and third indicator are the implementation of the role and function of internal auditors and the implementation of corporate performance assessment system. While other indicators are dominated by the respondents that the first and fourth indicators that make up the audit committee as well as the use of external auditors qualified and independent application is still classified in either category. The results of the total score of the scale of the answer are 1,060 with a percentage of $86.9 \%$. In general it can be concluded that the principle of transparency has been implemented very well. The application of the principle of responsibility. Of respondents indicate that the indicator first, second, and fourth, each of which is considered a social responsibility, to avoid abuse of power, and create a good business environment that are in either category. While all three indicators that make up the personal professional and adhere to ethical application is still quite good.

The results of the total score of the scale of the answer are 878 with a percentage of $72 \%$. Overall, the principle of responsibility has been implemented properly. Application of the principle of reasonableness. Indicators of the first, third, and fourth the company's application of the rules on the protection of the interests of shareholders, the implementation of the roles and responsibilities of the commissioner and management, and fair disclosure of any information that are in either category in its application. As for the second indicator which is to establish policies to protect against errors that come from within, its application is still classified in the category quite well. The results of the total score of the scale of the answer are 906 with a percentage of $74.3 \%$. Thus, it can be concluded that the overall implementation of the principle of fairness that are in either category. The application of the principle of independence. The first indicator that the use of experts in financial reporting is still in good enough category. While indicators of the second, third, and fourth namely avoiding the involvement of the influence of outside parties that are not in accordance with the principles of healthy corporate, avoid conflicts of interest, as well as the activity of the company is well run and are dynamic in both categories in its application. The results of the total score of the scale of the answer are 921 with a percentage of $75.5 \%$. Thus, it can be concluded that the implementation of the principle of independence in general have been executed well.

Recommendation: Based on research on the implementation of Good Corporate Governance (GCG) at PT Nusatara Infrastructure Tbk, then there are some suggestions that are expected by the researcher to be used as material for consideration by the company: On the principle of transparency, PT Nusantara Infrastructure Tbk should further develop information technology management and risk management the enterprise level, as well as more attention to the publication of financial information and other information material. On the principle of accountability, PT Nusantara Tbk Infrastructure should pay more attention on the establishment of an audit committee as well as the use of external auditors is qualified and independent. On the principle of responsibility, PT Nusantara Infrastructure Tbk should consider more social responsibility, avoiding of power and the creation of a good business environment. Companies also should emphasize matters related to the establishment of professional and personal ethics adhere. On the principle of fairness, PT Nusantara Infrastructure Tbk should pay more attention to matters concerning the company rules that protect the interests of shareholders, the role and responsibilities of the commissioner, and disclosure of information are reasonable. Companies also should emphasize matters relating to the establishment of policies to protect against errors that come from within. On the principle of independence, PT Nusantara Infrastructure Tbk should be focusing attention on the use of experts in the financial statements. Companies also should pay more attention on the involvement of the influence of outside parties that are not in accordance with the principles of healthy corporate, avoid conflicts of interest, as well as the implementation of good corporate activity and dynamic. 


\section{References}

Antosius, F. A. (2003). Corporate Governance, Issue 1. Jakarta: Prenhalindo.

Budianti. (2010). The Power of Good Corporate Governance: Theory and Implementation. Jakarta: Salemba Empat.

Faisal. (2003). Mekanisme Corporate Governance, Earnings Management and Financial Performance. Papers SNA X.

Febryanto, D. (2013). Analysis of Application of Good Corporate Governance (GCG) to the Company's Performance.

Gujarati. (1995). Econometric 1995.Basic. New York: Mc-Graw Hill.

Hadi, S. (1991). Methodology Research, Volume 3. Yogyakarta: Andi Offset.

Herwidayatmo. (2003). Implementation of GCG Capital Market Indonesia: Indonesian investors.

Moeljono, D. (2005). Cultured: Organizational Culture in Tantangan. Jakarta: Elex Media Komputindo.

The Code of Good Corporate Governance Indonesia. (2006). Jakarta: National Committee on Governance.

Pieris, J. and Nizam, J. W. (2008). Business Ethics \& Good Corporate Governance, Issue 2.Jakarta: Pelangi Cendekia.

Rastiani. (2009). Analysis implementation of the principles of Good Corporate Governance (GCG) on the performance of PT. Bank Rakyat Indonesia, Tbk.

Setyani, N. H. (2010). Implementation of Principles of Good Corporate Governance in Islamic Banking in Indonesia.

Sugiyono. (2007). Methods of Research Administration. Bandung: Alfabeta.

Sugiyono. (2011). Metodologi Research Bisnis. Bandung: Alfabeta.

Sugiyono. (2012). Qualitative and Quantitative Research Methods R \& D. Bandung: Alfabeta.

Sulistyanto, S. (2003). Good Corporate Governance: Did it work in Indonesia?

Sutedi, A. (2011). Good Corporate Governance, Issue 1, Moulds 1. Jakarta: Sinar Grafika.

Thomas, S. K. (2006). Good Corporate Governance and Its Application in Indonesia: Study Team of the Finance Ministry Bapepam-LK. 2010. Study on Guidelines for Good Corporate Governance in the Member States ACMF. Jakarta: Ministry of Finance Bapepam-LK. 9.

Single, F. S. \& Amin, W. T. (2002). Memahami concept of Corporate Governance, Issue 2.Jakarta: Harvarindo.

Usmansyah. (2003). Komitmen In Good Corporate Governance: Auditor Internal, Issue 12. Jakarta: Harvarindo. 